\title{
RENDAHNYA KUALITAS PENDIDIKAN INDONESIA, SALAH SIAPA ?
}

\section{Sri Nuryatin}

Program Studi Pendidikan IPS, FKIP Universitas Lambung Mangkurat

\section{Srinuryatin676@gmail.com}

Pendidikan merupakan proses yang terus menerus dan tidak berhenti, didalam proses pendidikan ini keluhuran martabat manusia, di pegang erat oleh manusia (yang terlibat dalam pendidikan ini) karena merupakan subjek dalam pendidikan maka di tuntut suatu tanggung jawab agar tercapai suatu hasil pendidikan yang lebih baik.

Terkait pendidikan formal, pendidikan formal sendiri adalah jalur pendidikan yang dilaksanakan disekolah atau tempat tertentu, diatur secara sistematis, memiliki jenjang dan batas waktu yang ditetapkan. Rendahnya kualitas pendidikan di Indonesia terbukti dari kualitas siswa, guru, sarana belajar dan lainnya yang membuat pendidikan semakin menurun.

Memprihatinkan, itulah gambaran kualitas pendidikan di Indonesia sekarang. Lantas siapakah yang masuk kategori perlu disalahkan dalam rendahnya kualitas pendidikan di Indonesia sekarang ini?

Apakah ini kesalahan negara yang tidak serius untuk meningkatkan pendidikan atau ini hanya opini-opini bahwa pemerintahlah yang harusnya bertanggung jawab soal permasalahan ini?

Namun jika dilihat realitanya memang benar, perhatian pemerintah masih terasa sangat minim, gambaran ini tercermin dari beragamnya masalah pendidikan yang makin rumit dan kompleks, gaji guru yang masih rendah terutama guru swasta dan guru 
honorer. Guru cenderung disalahkan karena dinilai lemah dalam menggali potensi siswa, sehingga banyak anak yang tidak bisa meraih prestasi belajar. Namun pemerintah sendiri lupa tidak memberi kesejahteraan yang layak untuk para guru. Padahal ketika gaji dan kesejahteraan guru tinggi, maka semakin banyak orang yang mau menjadi guru, ketika banyak minat ini, maka akan ada persaingan untuk menjadi guru. Persaingan itulah yang akan membuat level guru meningkat dan semakin baik. Ketika kualitas guru nya baik, maka siswa yang dihasilkan juga akan memiliki kualitas yang bagus, dan menjadi SDM yang berkualitas kelak yang dapat memberi kontribusi untuk negara.

Sarana dan prasarana disekolah juga memiliki andil dalam kualitas pendidikan, lebih parahnya masih terdapat kota atau desa yang sekolahnya tidak memiliki gedung atau tempat sendiri bahkan tidak layak. Ketimpangan sekolah antara kota besar dan daerah terpencil memang tidak bisa dipungkiri. Sangat terjadi perbedaan antara bangunan sekolah dan sarana prasarana yang disediakan.

Jika melihat negara-negara maju dalam meraih pendidikan berkualitas memang tidak murah, atau lebih tepatnya, tidak gratis. Pemerintah menjamin setiap warganya memperoleh pendidikan dan menjamin akses masyarakat bawah untuk mendapatkan pendidikan yang berkualitas. Harapan saya pendidikan di Indonesia bisa sejajar dengan pendidikan di negara-negara lain yang kualitas pendidikannya jauh lebih baik di Indonesia. 